\title{
An IR for the Global South or a Global IR?
}

\author{
Amitav Acharya
}

The field of international relations (IR) is witnessing growing efforts to challenge Western centrism and give more space and voice to the Global South. These efforts are happening under a variety of labels, such as, but not limited to, non-Western IR, postWestern IR, Global IR, etc.

To be sure, attempts to "bring the Global South in" by highlighting and generalizing from its contexts and challenges are not new. One could think of several examples, with Dependency theory and, somewhat later, Postcolonialism being two of the most prominent approaches. But recent efforts have been broader and targeted the entire discipline of IR, especially its major theories and concepts. And they have brought in a wider range of theoretical perspectives than Marxism and Postcolonialism, including Constructivism (Acharya), English School (Buzan) and even some realists (e.g. Mohammed Ayoob's Subaltern Realism”).

But labels overlap and can be confusing. Does post-Western subsume or exclude pre-Western or premodern, or preWestphalian histories and institutions? Are the distinctions between West and non-West meaningful? (They are increasingly blurred, but alas, the major IR theories are yet to reflect this) What is the difference between "nonWestern" and "post-Western"? I cannot speak for "post-Western", but "non-Western" IR Theory (NWIRT), when it was first advanced in 2007, called for making critical advances to existing IR theories with the infusion of the ideas, voices and experiences from the Global South (China included). But it did not call for displacing or supplanting existing IR knowledge and theories. Displacement is both impractical and undesirable. I am not sure how far a "post-Western" IR Theory would seek such displacement.

\section{Avoiding Parallelism and Embracing Pluralism}

In the meantime, the idea of Global IR, as outlined and developed during the 2015 ISA Presidential Year (Acharya, "Global IR and
Regional Worlds: A New Agenda for International Studies, ISQ, 58:4, 2014), transcends categories such as non-Western and post-Western IR. It argues that the discourse about the future of IR should involve multiple but overlapping conversations. It should not be an exclusive discourse within the Global South community of scholars, but a dialogue among different theoretical and epistemological approaches. It should not run parallel to other debates about the future of IR, but intersect with them. Discourses that view the Global South or regions like East Asia as distinct and different often turn inward and as it participants draw comfort from each other without making much impact on the mainstream IR scholars.

Global IR calls for theoretical and epistemological pluralism and eclecticism, across the mainstream-critical theory divide. The aim is to end the exclusion and marginalization of the Global South with the help of a variety of approaches. This does not mean leaving mainstream theories such as Realism, Liberalism and some forms of Constructivism as is, but challenging them to shed their ethnocentrism and become more inclusive.

To be sure, there are issues that are of special concern to the Global South. Such issues might include under/development, regionalism, gender, human security etc. But these issues have received attention from both mainstream and critical IR literature, albeit in different ways. One notable exception is race which has been ignored or studied in a highly superficial way in the mainstream literature, often in a patronizing manner. In some cases, as with race and women, their study by Western scholars had led to what I have called neo-marginalization.

There may be other issues out there that are so unique or distinctive to the economic, political and security predicament of the Global South as to deserve special attention. But creating a separate school to study them may be unhelpful and unnecessary. For one thing, the existing IR theories are 
neither uniform nor unchanging when it comes to reflecting and addressing the more specific concerns of the Global South. Some mainstream scholars (rather than the theories they identify with) in the West continue to resist such broadening, but the theories themselves are not a closed shop when it comes to engaging with the issues and challenges facing the Global South.

At the same time, I believe that Global South scholarship should not limit itself to studying Global South issues, or issues that are of special concern to the states and peoples of the Global South. In a globalized and Multiplex World, it is increasingly difficult to draw any sharp lines between Northern and Southern issues. Global South scholars should cast their net widely and comprehensively. The challenge is to forge an inclusive global dialogue.

\section{Second Generation Challenges}

In developing such a paradigm of Global IR, it is no longer enough to say that the IR suffers from Western centrism. Nor is it enough to say that we should develop concepts and theories from non-Western history and practice. These first generation efforts have run their course. The second generation challenge for those who want to move IR forward by bringing the Global South "in" is to demonstrate that concepts and theories derived from the nonWestern context can also apply beyond that specific national or regional context from which they are initially derived. This is especially a challenge for the Chinese and other such Schools of IR that are now emerging. While helpful to the task of pluralizing IR, they seem preoccupied with demonstrating how existing IR theories fail to apply to their nations or regions, but end up offering "alternative" understandings and approaches that do not travel beyond their nations and regions.

Another key challenge is to bring more history and civilizations into the Global South IR scholarship. I begin my First Year Seminar at American University, entitled "Civilizations and World Orders: An Introduction to Global International Relations," by telling the students that if they study IR from with the nation-state as the basic point of reference, they are dealing with at most 500 hundred years of history during which the West has been the dominant element. But if they study IR from the vantage point of civilizations, then they have 5000 years of history to play with, out of which Westphalianism/Western dominance is but a brief period.

The place of history in Global South scholarship is rather uneven. When one talks of Latin American or African voices in IR, the emphasis seems to be on colonial and postcolonial, rather than precolonial history (or pre-Columbian, although the latter term kind of obscures the general comparability aspect of Western colonialism). The focus is on contemporary marginalization, not discovery, if not recovery of their alternative pasts. This creates an ethnocentrism within the Global South, or a kind of self-marginalization. This needs to change. I have not seen much attempt by scholars whether from the Americas (North, Central and South) or elsewhere to conceptualize from pre-Colombian history, including Maya, Inca, etc. This is in marked contrast to the efforts by scholars to bring Chinese and Indian civilizational history into IR.

Last but not the least, efforts to develop a more inclusive discipline of IR, while attracting new scholars and generating research at the higher levels, is yet to filter down to the level of basic undergraduate textbooks. There is yet to be an undergraduate textbook which reflects the global heritage and scope of the discipline. The most popular texts remain stubbornly Westphalic, and with limited exceptions (more in Europe than in the US), pay lip-service to non-Western histories, voices and perspectives. To remove this bias in teaching undergraduates in IR is an urgent need but no easy task, because of the near hegemony of a few textbook publishers in the West. This is perhaps where groups like WISC and regional and national associations can play a meaningful role, provided they look past national or regional exceptionalisms and interact with each other and along with the larger community of Western and nonWestern scholars that is concerned with the Global South. The shared task is not to build an IR for the Global South but a Global IR. 
*Amitav Acharya saat ini menjabat sebagai ketua Transnational Challenges and Governance di UNESCO, menjabat sebagai ketua ASEAN Studies Initiative, dan juga merupakan seorang Profesor di bidang Hubungan Internasional di School of International Service, American University, Washington D.C.. Amitav adalah penulis dari buku berjudul Whose Ideas Matter? (Cornell 2009), The Making of Southeast Asia (Cornell 2013), Rethinking Power, Institutions and Ideas in World Politics (Routledge 2013) dan The End of American World Order (Polity 2014, Oxford 2015).

** Tulisan ini juga dapat dilihat di laman EInternational Relations dengan judul An IR for the Global South or a Global IR? Oleh Amitav Acharya (21 Oktober 2015) di tautan: http://www.e-ir.info/2015/10/21/an-ir-forthe-global-south-or-a-global-ir/ 
